Zwiech P., Wertykalna segregacja ptciowa w teoriach ekonomicznych na przyktadzie państw Unii Europejskiej, „Ekonomia i Prawo”, Polszakiewicz B., Boehlke J. (red.), Tom XII, nr 3/2013, ss. 425-439. DOI: http://dx.doi.org/10.12775/EiP.2013.032

\title{
WERTYKALNA SEGREGACJA PŁCIOWA W TEORIACH EKONOMICZNYCH NA PRZYKŁADZIE PAŃSTW UNII EUROPEJSKIEJ
}

\section{STRESZCZENIE}

Celem niniejszego artykułu jest przedstawienie i uporządkowanie determinant wertykalnej segregacji płciowej w sferze pracy zawodowej opisanych w teoriach ekonomicznych oraz ocena stopnia wertykalnej segregacji płciowej w państwach Unii Europejskiej. Do celu głównego przyporządkowano 3 zadania badawcze, a mianowicie: wskazanie determinant segregacji wertykalnej występujących w teoriach ekonomicznych, analizę wysokości wskaźnika wertykalnej segregacji płciowej w państwach Unii Europejskiej oraz analizę wysokości wskaźnika relacyjnego wertykalnej segregacji płciowej w państwach Unii Europejskiej.

Słowa kluczowe: nierówności i pomiar, rynek pracy, gender studia Klasyfikacja JEL: D63, J01, J16

VERTICAL GENDER SEGREGATION IN THE ECONOMIC THEORIES WITHIN THE EUROPEAN UNION

\section{SUMMARY}

The objective of this paper is to describe and organise the determinants of vertical gender segregation in the workplace described in the economic theories as well as

* Patrycja Zwiech, Uniwersytet Szczeciński, Wydział Nauk Ekonomicznych i Zarządzania, Katedra Organizacji i Zarządzania, tel.: +48 600094 444, e-mail: patrycjazwiech@tlen.pl. 
to evaluate vertical gender segregation in Member States. In order to achieve the said objective, three tasks were performed, namely: showing determinants of vertical gender segregation in the economic theories, analysing the index of vertical gender segregation in Member States and analysing the level of relational index of gender segregation in the European Union.

Keywords: inequality and measurement, labor market, gender studies

JEL Classification: D63, J01, J16

\section{WSTĘP}

Segregacja sprowadza się do dyskryminacyjnego (faktycznego lub prawnego) oddzielenia od siebie $\mathrm{w}$ ramach jednego społeczeństwa, dwóch lub większej liczby grup ludzi, według różnych kryteriów. Segregacja może łączyć się z przekonaniem o nierównym statusie tych grup, może też być efektem dominacji jednej z grup ${ }^{1}$.

Segregacja zawodowa może przybierać dwie formy: horyzontalną (poziomą) i wertykalną (pionową). Segregacja horyzontalna polega na tym, że aktywność zawodowa określonej grupy zawodowej (w przypadku segregacji płciowej - kobiet) koncentruje się w innych, często mniej licznych, gorzej płatnych i powiązanych z mniejszym prestiżem dziedzinach zatrudnienia. Segregacja wertykalna sprowadza się do znacznie niższego udziału określonych grup (w przypadku segregacji płciowej - kobiet) w gremiach decyzyjnych.

$Z$ różnych powodów nie we wszystkich zawodach i nie na wszystkich stanowiskach kobiety są akceptowane. Łatwo wchodzić kobietom do zawodów niskopłatnych i dających małe możliwości awansu, podczas gdy do wielu zawodów intratnych nie mają dostępu lub lub jest on bardzo ograniczony.

Relatywny udział segregacji horyzontalnej i wertykalnej o niższych zarobkach kobiet oszacował P.J. Sloane ${ }^{2}$. Wyniki jego badań są następujące - segregacja horyzontalna wpływa w 20-27\% na różnicę w zarobkach między kobietami i mężczyznami. Fakt podejmowania przez kobiety określonych zawodów na początku ich kariery nie obniża ich dochodów w takim stopniu jak niepowodzenia we wspinaniu się po drabinie zawodowej do wyższych i lepiej płatnych stanowisk, gdy już weszły do określonej grupy zawodowej. Dyskrymina-

${ }_{1}$ M. Gawrycka, J. Wasilczuk, P. Zwiech, Szklany suft i ruchome schody - kobiety na rynku pracy, CeDeWu sp. z o.o., Warszawa 2007, s. 29.

2 P.J. Sloane, Sex Differentials: Structure, Stability and Change, [w:] N. Gregory, W. Thomson (red.), A Portrait of Pay 1970-1982: An Analysis of the New Earnings Survey, Clarendon, Oxford 1990, s. 146. 
cja stanowiskowa ${ }^{3} \mathrm{w}$ większym stopniu determinuje więc pozycję kobiet niż dyskryminacja zawodowa. W niniejszym artykule autorka skupiła się na segregacji wertykalnej.

Celem niniejszego artykułu jest przedstawienie i uporządkowanie determinant wertykalnej segregacji zawodowej oraz ocena stopnia wertykalnej segregacji płciowej w państwach europejskich. Do celu głównego zostały przyporządkowane następujące problemy badawcze:

1. Wskazanie determinant segregacji wertykalnej występujących $\mathrm{w}$ teoriach ekonomicznych.

2. Analiza wysokości wskaźnika wertykalnej segregacji płciowej w państwach Unii Europejskiej.

3. Analiza wysokości wskaźnika relacyjnego wertykalnej segregacji płciowej w państwach Unii Europejskiej.

\section{SEGREGACJA PŁCIOWA W TEORIACH EKONOMICZNYCH}

Segregacja płciowa sprowadza się do oddzielenia kobiet i mężczyzn w sferze pracy zawodowej. Prowadzi do relatywnego upośledzenia kobiet $\mathrm{w}$ nagrodach za pracę i przyczynia się do nierówności płci w sferze pracy zawodowej. Wyjaśnienia przyczyn wertykalnej i horyzontalnej segregacji płciowej można szukać w następujących teoriach ekonomicznych: w hipotezie stłoczenia w nielicznych zawodach, teorii peryferyjności D. Morse'a, teorii dyskryminacji na rynku pracy K. Offe'a i K. Hinrichsa, teorii rynku pracy jako areny R. Loveridge'a i A.L. Moka, hipotezach S. Polacheka i H. Zellner opartych na teorii buman capital oraz teoriach odnoszących się do segmentacji rynku pracy (segmentacja statystyczna rynku pracy, koncepcja rynków wewnętrznych i zewnętrznych, teoria dualnego).

Hipoteza stłoczenia w nielicznych zawodach ${ }^{4}$ zakłada, że liczebność kobiet $\mathrm{w}$ pewnych zawodach jest sztucznie zwiększona, przez co ich zarobki są niższe. Jest to wynik segregacji zawodowej, która pociąga za sobą konieczność współzawodniczenia o miejsca pracy w zawodach, w których kobiety są akceptowane. Powodem stłoczenia w ograniczonej liczbie zawodów jest niedopuszczanie kobiet do wielu rodzajów prac przez pracodawców i związki za-

${ }^{3}$ P. Zwiech, Rodzaje dyskryminacji kobiet na rynku pracy, „Polityka Społeczna” nr 4/2011, s. 17.

${ }^{4}$ Teoria ta została przedstawiona w: F.Y. Edgeworth, Equal pay to men and women for equal work, „Economic Journal” nr 32/1922, s. 431-457 oraz dopracowana przez: B.R. Bergman, The Effect on White Incomes of Discrimination in Employment, „Journal of Political Economy” nr 79/ 1971, s. 294-229. 
wodowe reprezentowane przez robotników - mężczyzn ${ }^{5}$. Hipoteza ta odnosi się do segregacji horyzontalnej, nie tłumaczy natomiast determinant segregacji wertykalnej.

Teoria peryferyjności D. Morse'a ${ }^{6}$ wskazuje, że w „gorszych” zawodach oraz w "gorszych" branżach pracują kategorie demograficzne o niskim statusie, w tym kobiety. Występują tu wzajemne oddziaływania. $Z$ jednej strony zawód lub branża może obniżać status pracowników, a z drugiej poszczególne kategorie pracownicze mogą obniżać status zawodów lub branż. Niższy status zawodowy kobiet niż mężczyzn powoduje przypisanie ich do "gorszych” zawodów i pozycji, tworząc zarówno segregację horyzontalną, jak i wertykalną.

Teoria dyskryminacji na rynku pracy K. Offe'a i K. Hinrichsa wskazuje, że w "gorszych” zawodach, w "gorszych” branżach oraz na "gorszych” pozycjach pracują członkowie tzw. grup „stwarzających problemy”, do których autorzy zaliczyli także kobiety. Horyzontalna i wertykalna segregacja zawodowa jest pochodną podziału populacji na część „stwarzającą problemy” i część „niestwarzającą problemów" dla pracodawców.

Teoria rynku pracy jako areny R. Loveridge'a i A.L. Moka ${ }^{7}$ wskazuje na przyczyny zaliczania kobiet do dyskryminowanych grup społecznych. Autorzy wskazują, że upośledzenie niektórych grup społecznych, w tym kobiet, wynika z małych możliwości i chęci zorganizowania się w grupę nacisku.

S. Polachek i H. Zellner przedstawili hipotezy wyjaśniające segregację zawodową według płci w oparciu o teorię human capital. Obie hipotezy przyjmują założenie, że mężczyźni i kobiety wybierają zawody, które maksymalizują ich zarobki w ciągu życia. Ze względu na różnice w ciągłości zatrudnienia odmienne wybory zawodowe kobiet i mężczyzn są racjonalne, ponieważ przynoszą korzyści finansowe ${ }^{8}$. Hipoteza S. Polacheka opiera się na założeniu, że kwalifikacje zawodowe kobiet w czasie przerw w zatrudnieniu dezaktualizują się lub ulegają zapomnieniu, co pociąga za sobą obniżenie płacy po powrocie do pracy. Ryzyko nie jest jednakowe we wszystkich zawodach.

${ }_{5}^{5}$ I. Reszke, Nierówności ptci w teoriach. Teoretyczne wyjaśnienia nierówności ptci w sferze pracy zawodowej, IFIS PAN, Warszawa 1991, s. 82-83.

${ }^{6}$ D. Morse, The Peripheral Worker, Columbia University Press, London 1969.

7 R. Loveridge, A.L. Mok, Theories of Labour Market Segmentation. A Critique, Martinus Nijhof, Hague - Boston - London 1979.

${ }^{8}$ Obie hipotezy sprawdzała P. England. Wyniki jej badania nie popierają jednak żadnej z tych hipotez. Stwierdziła ona, że kobiety zarabiają więcej w zawodach męskich niż w kobiecych. Nie mogą więc maksymalizować zarobków całego życia, wybierając zawody kobiece. Zdaniem P. England teoria human capital nie może wyjaśnić segregacji zawodowej według płci - zob. P. England, Wage Appreciation and Depreciation: A Test of Neoclassical Economic Explanations of Occupational Sex Segregation, „Social Forces” nr 3 (62)/1984, s. 50-75. 
Kobiety wybierają więc zawody, w których obniżenie płacy jest najmniejsze9 H. Zellner twierdzi natomiast, że w niektórych zawodach płace są początkowo niskie, a następnie wzrastają. $W$ innych zawodach płace są początkowo wyższe, ale ich przyrost w późniejszym okresie jest bardzo mały. Zdaniem H. Zellner wiele kobiet nie pracuje dostatecznie długo, by skorzystać ze stopniowego przyrostu płac. Dlatego więcej kobiet niż mężczyzn wybiera zawody drugiego typu, aby uzyskać maksymalizację swoich zarobków w ciągu życia ${ }^{10}$. Segregacja zawodowa jest więc wynikiem świadomych wyborów dokonywanych przez obie płcie opartych na oczekiwaniach co do przyszłych zarobków.

Przyczyn segregacji wertykalnej i horyzontalnej można także szukać w teoriach segmentacji rynku pracy. Teorią odnoszącą się do segmentacji rynku pracy jest segmentacja statystyczna rynku pracy, która sprowadza się do podziału rynku pracy na segmenty według widocznych, łatwych do określenia cech pracowników. Takim kryterium stratyfikacyjnym podziału populacji na grupy jest m.in. płeć. Pracodawcy wykorzystują widoczny wyróżnik - płeć - jako przybliżony wskaźnik posiadania pożądanych (lub niepożądanych) cech. Niezgodność cech przypisywanych grupom dyskryminowanym z wymaganiami stawianymi kandydatom prowadzi do statystycznej dyskryminacji. W rezultacie osoby z grup dyskryminowanych otrzymują prace $z$ jednej strony niżej płatne, a $z$ drugiej $w$ ogóle mogą nie być zatrudniane na pewnych stanowiskach pracy, co prowadzi do segregacji zawodowej.

Według koncepcji rynków zewnętrznych i wewnętrznych ${ }^{11}$ rynek pracy składa się z dwóch odmiennych, oddzielonych od siebie rynków - rynków zewnętrznych i wewnętrznych. Zewnętrzny rynek pracy obejmuje obszary znajdujące się poza rynkami wewnętrznymi. Oba rynki z jednej strony gwarantują różne warunki zatrudnienia, a $\mathrm{z}$ drugiej stawiają inne wymagania pracownikom. Osoby pracujące na rynkach wewnętrznych są niejako oddzielone od pozostających na rynku zewnętrznym. Konkurencja dokonuje się na każdym z rynków osobno. Dostęp do rynku wewnętrznego jest ograniczony, zwłaszcza do miejsc pracy stojących wysoko w hierarchii zakładowej. Pracodawcy na wewnętrznym rynku pracy oczekują ciągłości zatrudnienia, przez co spychają wybrane grupy społeczne do części marginesowej lub w ogóle ich nie zatrudniają. Natomiast firmy działające na zewnętrznym, konkurencyjnym ryn-

9 S. Polachek, Occupational Segregation among Women: Theory, Evidence and a Prognosis, [w:] C. Lloyd (red.), Women in the Labor Market, Columbia University Press, Columbia 1979, s. $120-147$.

${ }^{10}$ H. Zellner, The Determinants of Occupational Segregation, [w:] C. Lloyd (red.), Sex, Discrimination and the Division of Labor, Columbia University Press, Columbia 1975, s. 278-295.

11 P. Doeringer, M. Piore, Internal Labor Markets and Manpower Analysis, D.C. Heath, Lexington Mass. 1971, s. 20. 
ku pracy nie stosują tak nowoczesnej, skomplikowanej technologii ani takiej organizacji pracy, jaka cechuje wewnętrzne rynki pracy i dlatego nie wymagają od pracowników ciągłości pracy, ale też nie dają im pewności zatrudnienia. Podział rynku pracy na rynki wewnętrzne i rynki zewnętrzne pociąga za sobą segmentację zawodową populacji.

Teorie dualnego (dwojakiego) rynku pracy ${ }^{12}$ opierają się na założeniu o podziale rynku pracy na pierwszorzędny i drugorzędny, o odmiennych determinantach zatrudnienia i płac w każdym $\mathrm{z}$ tych segmentów oraz o ograniczonej mobilności między segmentami. Segment pierwszorzędny charakteryzuje się miejscami pracy dającymi wysokie płace, dobre warunki pracy oraz możliwości awansowania. W segmencie drugorzędnym miejsca pracy charakteryzują się gorszymi płacami, gorszymi warunkami pracy, mniejszymi szansami awansu, brakiem pewności pracy i wysoką fluktuacją pracowników ${ }^{13}$. Zasadniczy podział rynku pracy przebiega więc nie między wykwalifikowanymi i niewykwalifikowanymi pracownikami, a między „dobrymi” i „złymi” miejscami pracy $^{14}$. Segmentacja rynku pracy przenosi się więc na segregację zawodową.

\section{METODOLOGIA BADANIA}

Dla zobrazowania wertykalnej segregacji płciowej w poszczególnych państwach Unii Europejskiej wykorzystano następujące wskaźniki:

- wskaźnik wertykalnej segregacji płciowej $S_{p w}$;

— wskaźnik relacyjny wertykalnej segregacji płciowej $R S_{p w}$.

Wskaźnik segregacji płciowej w odniesieniu do zatrudnienia został opracowany przez OECD w 1980 roku. Segregacja płciowa została zdefiniowana jako różnica między odsetkiem mężczyzn i kobiet zatrudnionych w określonej kategorii zawodowej lub w określonym przemyśle. Miarą segregacji jest wskaźnik nierównoważności, który informuje o odsetku kobiet lub mężczyzn, którzy powinni zmienić pracę, żeby proporcje płci w danej kategorii zawodowej były zachowane. W przypadku braku segregacji płciowej wynosi on 0 ,

${ }^{12}$ Koncepcję dualnego rynku pracy wprowadził, jako konstrukcję teoretyczną M. Piore w 1969 roku. Sprecyzowana została w pracach P. Doeringera i M. Piore'a w roku 1971 - zob. M. Piore, The Dual Labor Market. Theory and Applications, [w:] R. Barringer, S.H. Beer (red.), The State and the Poor, Winthrop, Cambridge Mass, 1970; P. Doeringer, M. Piore, Internal Labor Markets and Manpower Analysis, D.C. Heath, Lexington Mass, 1971.

${ }_{13}$ M.J. Piore, Notes for Theory of Labor Market Stratification, [w:] R.C. Edwards, M. Reich, D.M. Gordon (red.), Labor Market Segmentation, D.C. Heath, Lexington Mass, 1975, s. 126.

${ }_{14}$ A.L. Kallenberg, K. Sorensen, The Socjology of Labor Markets, „Annual Review of Socjology”, nr 5/1979, s. 351-379. 
a gdy segregacja jest całkowita - 100. Dla całej gospodarki oblicza się go, sumując wskaźniki segregacji płciowej dla wszystkich zawodów lub przemysłów.

Wskaźnik segregacji płciowej mierzony jest stopniem różnicy między rzeczywistym udziałem kobiet wśród ogółu zatrudnionych w „przeciętnym” zawodzie lub przemyśle, a udziałem kobiet w „danym” zawodzie lub przemyśle. Wskaźnik segregacji płciowej można zapisać wzorem:

$$
S_{p}=\left(U_{k 0}-U_{k n}\right)=\left(\frac{L_{k 0}}{L_{k m 0}}\right) \times 100-\left(\frac{L_{k n}}{L_{k m n}}\right) \times 100,
$$

gdzie:

$S_{p} \quad-$ wskaźnik segregacji płciowej,

$U_{k 0}$ - udział kobiet wśród ogółu zatrudnionych,

$U_{k n} \quad$ - udział kobiet wśród zatrudnionych w n-tym zawodzie lub przemyśle,

$L_{k 0}$ - liczba zatrudnionych kobiet,

$L_{k m 0}$ - liczba zatrudnionych,

$L_{k n} \quad$ - liczba kobiet zatrudnionych w n-tym zawodzie lub przemyśle,

$L_{k m n}$ - liczba zatrudnionych w n-tym zawodzie lub przemyśle.

W przypadku rozpatrywania segregacji pionowej wskaźnik wertykalnej segregacji płciowej można zapisać wzorem:

$$
S_{p w}=\left(U_{k 0}-U_{k 1}\right)=\left(\frac{L_{k 0}}{L_{k m 0}}\right) \times 100-\left(\frac{L_{k 1}}{L_{k m 1}}\right) \times 100,
$$

gdzie:

$S_{p w}$

$U_{k 1}$

$L_{k 1}$

$L_{k m 1}$

$U_{k 0}, L_{k 0}, L_{k m 0}-$ jak we wzorze (1).

Wskaźnik $S_{p}$ wskazuje o ile udział kobiet w badanym zawodzie lub przemyśle jest większy (w przypadku wartości ujemnej) lub mniejszy (w przypad- 
ku wartości dodatniej) od przeciętnego udziału kobiet wśród zatrudnionych. W przypadku gdy jest zbliżony do 0 , mamy do czynienia z sytuacją braku nierówności między płciami. Wskaźnik $S_{p w}$ wskazuje, o ile udział kobiet w grupie zawodowej menedżerów (osób zajmujących stanowiska kierownicze i decyzyjne) jest większy (w przypadku wartości ujemnej) lub mniejszy (w przypadku wartości dodatniej) od przeciętnego udziału kobiet wśród zatrudnionych. W przypadku, gdy jest zbliżony do 0, mamy do czynienia z sytuacją braku nierówności między płciami.

Wskaźnik relacyjny segregacji płciowej można zdefiniować jako procentową różnicę między udziałem kobiet wśród ogółu zatrudnionych a udziałem kobiet wśród zatrudnionych w danym zawodzie lub przemyśle. Można zaproponować następujące wzory:

$$
\begin{gathered}
R S_{p}=\frac{S_{p}}{U_{k 0}} \times 100, \\
R S_{p}=\frac{U_{k 0}-U_{k n}}{U_{k 0}} \times 100, \\
R S_{p}=\frac{\frac{L_{k 0}}{L_{k m 0}}-\frac{L_{k n}}{L_{k m n}}}{\frac{L_{k 0}}{L_{k m 0}}} \times 100,
\end{gathered}
$$

gdzie:

$R S_{p}$ - wskaźnik relacyjny segregacji płciowej,

$S_{p}, U_{k 0}, U_{k n}, L_{k 0}, L_{k m 0}, L_{k n}, L_{k m n}$ - oznaczenia jak we wzorach (1) i (2).

W przypadku rozpatrywania segregacji wertykalnej można zaproponować następujące wzory wskaźnika relacyjnego segregacji wertykalnej:

$$
\begin{gathered}
R S_{p w}=\frac{S_{p w}}{U_{k 0}} \times 100, \\
R S_{p w}=\frac{U_{k 0}-U_{k 1}}{U_{k 0}} \times 100,
\end{gathered}
$$




$$
R S_{p w}=\frac{\frac{L_{k 0}}{L_{k m 0}}-\frac{L_{k 1}}{L_{k m 1}}}{\frac{L_{k 0}}{L_{k m 0}}} \times 100,
$$

gdzie:

$R S_{p}$ - wskaźnik relacyjny segregacji wertykalnej,

$S_{p w}, U_{k 0}, U_{k 1}, L_{k 0}, L_{k m 0}, L_{k 1}, L_{k m n 1}-$ oznaczenia jak we wzorach (1) (2).

Wskaźnik $R S_{p}$ wskazuje o ile procent udział kobiet w badanym zawodzie lub przemyśle jest większy (w przypadku wartości ujemnej) lub mniejszy (w przypadku wartości dodatniej) od przeciętnego udziału kobiet wśród zatrudnionych. W przypadku, gdy jest zbliżony do 0, mamy do czynienia z sytuacją braku nierówności między płciami. Wskaźnik $R S_{p w}$ wskazuje, o ile procent udział kobiet $\mathrm{w}$ grupie zawodowej menedżerów jest większy (w przypadku wartości ujemnej) lub mniejszy (w przypadku wartości dodatniej) od przeciętnego udziału kobiet wśród zatrudnionych. W przypadku gdy jest zbliżony do 0, mamy do czynienia z sytuacją braku nierówności między płciami.

W badaniu zastosowano dane empiryczne $z$ badania Structure of Earnings Survey z lat 2002, 2006 i 2010 z bazy Eurostat (opublikowane odpowiednio w listopadzie 2004 r., 2008 r. i 2012 r.; stan na 20.02.2013 r.). Dla obliczeń wykorzystano dane skwalifikowane według klasyfikacji ISCO88 (dla 2002 i 2006 roku ISCO1 i Total) oraz ISCO08 (dla roku 2010 - OC1 i Total).

\section{WSKAŹNIK WERTYKALNEJ SEGREGACJI PŁCIOWEJ W KRAJACH UE}

Wskaźnik wertykalnej segregacji płciowej $S_{p w}$ wskazuje, o ile udział kobiet $\mathrm{w}$ grupie zawodowej menedżerów jest większy (w przypadku wartości ujemnej) lub mniejszy (w przypadku wartości dodatniej) od przeciętnego udziału kobiet wśród zatrudnionych. Ukazuje więc, jakie jest zróżnicowanie między udziałem kobiet wśród ogółu zatrudnionych a udziałem kobiet wśród osób zajmujących stanowiska kierownicze i decyzyjne. Wyniki przeprowadzonych badań przedstawiono w tabeli 1 . 
Tabela 1. Wskaźnik wertykalnej segregacji płciowej w krajach UE w latach 2002, 2006 i 2010

\begin{tabular}{|c|c|c|c|}
\hline \multirow{2}{*}{ WYSZCZEGÓLNIENIE } & \multicolumn{3}{|c|}{$S_{p w}$} \\
\hline & 2002 & 2006 & 2010 \\
\hline Francja & 2,7 & b.d. & b.d. \\
\hline Węgry & 9,7 & 10 & 12 \\
\hline Polska & 9,8 & 8,1 & 4,4 \\
\hline Czechy & 10,8 & 13,6 & 15 \\
\hline Łotwa & 11,1 & 13,8 & 10,2 \\
\hline Litwa & 11,2 & 11,2 & 13,5 \\
\hline Portugalia & 11,7 & b.d. & b.d. \\
\hline Bułgaria & 12,1 & 14 & 8,6 \\
\hline Rumunia & 12,2 & b.d. & b.d. \\
\hline Słowacja & 12,3 & 12 & 12,3 \\
\hline Grecja & 13,6 & b.d. & b.d. \\
\hline Szwecja & 14 & b.d. & b.d. \\
\hline Malta & 14,5 & b.d. & 12,6 \\
\hline Belgia & 14,9 & b.d. & b.d. \\
\hline Finlandia & 14,9 & b.d. & b.d. \\
\hline Estonia & 16,2 & 20,1 & 20,2 \\
\hline Wielka Brytania & 16,4 & 15 & 15,3 \\
\hline Luksemburg & 17 & b.d. & b.d. \\
\hline Hiszpania & 18,5 & 17,2 & 14,6 \\
\hline Stowenia & 18,8 & 13,8 & 12,9 \\
\hline Holandia & 21,2 & 20,2 & 19,4 \\
\hline Włochy & 22,3 & b.d. & b.d. \\
\hline Dania & 22,5 & b.d. & b.d. \\
\hline Austria & 22,6 & b.d. & b.d. \\
\hline Niemcy & 23 & 21 & b.d. \\
\hline Irlandia & 24,4 & 13,1 & 9,8 \\
\hline Cypr & 28,2 & 30,3 & 27,2 \\
\hline
\end{tabular}

b.d. - brak danych

Źródło: opracowanie własne na podstawie: Structure of Earnings Survey 2002, 2006, 2010, Eurostat (20.02.2013).

We wszystkich badanych państwach udział kobiet wśród ogółu zatrudnionych był większy od udziału kobiet wśród osób z I wielkiej grupy zawodowej. Udział kobiet $\mathrm{w}$ gremiach decyzyjnych $\mathrm{w}$ sferze pracy zawodowej jest więc mniejszy od ich udziału $\mathrm{w}$ zatrudnieniu. W najmniejszym stopniu to zjawisko występuje we Francji, gdzie udział kobiet w zatrudnieniu jest większy o 2,7 punktu procentowego od udziału kobiet w gremiach decyzyjnych, w największym na Cyprze, gdzie ta różnica sięga 28,2 punktu procentowego. 
Stosując pozycyjne miary tendencji centralnej, wyróżniono trzy grupy państw: państwa o niskim wskaźniku wertykalnej segregacji płciowej (0-12,2), do których zaliczono: Francję, Węgry, Polskę, Czechy, Łotwę, Litwę, Portugalię, Bułgarię i Rumunię, państwa o średnim wskaźniku (12,3-17,0) - Słowacja, Grecja, Szwecja, Malta, Belgia, Finlandia, Estonia, Wielka Brytania, Luksemburg i państwa o wysokim wskaźniku (powyżej 17,1) - Hiszpania, Słowenia, Holandia, Włochy, Dania, Austria, Niemcy, Irlandia i Cypr.

$\mathrm{Na}$ podstawie powyższych danych (lub raczej z powodu braku danych) nie można dokonać natomiast porównań zmian w czasie między poszczególnymi krajami. Można jednakże analizować zmiany tego zróżnicowania w czasie dla wybranych państw i można zaobserwować w latach 2002-2010 tendencję zmniejszania się tego zróżnicowania - w 10 państwach wskaźnik uległ zmniejszeniu (Polska, Łotwa, Bułgaria, Malta, Wielka Brytania, Hiszpania, Słowenia, Holandia, Irlandia, Cypr), w 4 zwiększeniu (Węgry, Czechy, Litwa, Estonia), a w 1 pozostał niezmieniony (Słowacja).

\section{WSKAŹNIK RELACYJNY WERTYKALNEJ SEGREGACJI PŁCIOWEJ W KRAJACH UE}

Sama różnica w udziałach kobiet w zatrudnieniu i w I grupie zawodowej wyrażona wskaźnikiem $S_{p w}$ nie obrazuje jednak całości sytuacji. Lepszym wskaźnikiem do zobrazowania nierówności między płciami w dziedzinie segregacji wertykalnej jest kolejny wskaźnik - wskaźnik relacyjny segregacji wertykalnej. W tabeli 2. zobrazowano wysokości tego wskaźnika w poszczególnych krajach europejskich.

Wskaźnik $R S_{p w}$ wskazuje, o ile procent udział kobiet w gremiach decyzyjnych jest większy lub mniejszy od przeciętnego udziału kobiet wśród zatrudnionych. Dla wszystkich badanych państw wskaźnik ten jest dodatni, czyli udział kobiet w gremiach decyzyjnych jest mniejszy od udziału kobiet wśród zatrudnionych, najmniejszy jest we Francji $(7,6)$ - co oznacza, że udział kobiet w gremiach decyzyjnych w tym państwie jest o 7,6\% mniejszy od udziału kobiet wśród zatrudnionych, a największy we Włoszech $(68,6)$ - udział kobiet $\mathrm{w}$ gremiach decyzyjnych $\mathrm{w}$ tym państwie aż o $68,6 \%$ mniejszy od udziału kobiet wśród zatrudnionych.

Stosując pozycyjne miary tendencji centralnej, wyróżniono trzy grupy państw: państwa o niskim wskaźniku relacyjnym segregacji płciowej (0-26,1), do których zaliczono: Francję, Węgry, Polskę, Litwę, Łotwę, Bułgarię, Czechy, Słowację i Rumunię, państwa o średnim wskaźniku (26,2-46,8) - Portugalia, 
Wielka Brytania, Estonia, Grecja, Finlandia, Słowenia, Szwecja, Irlandia, Malta i państwa o wysokim wskaźniku (powyżej 46,9) - Belgia, Holandia, Hiszpania, Luksemburg, Dania, Austria, Niemcy, Cypr i Włochy.

Tabela 2. Wskaźnik relacyjny wertykalnej segregacji płciowej w krajach UE w latach 2002, 2006, 2010

\begin{tabular}{|c|c|c|c|}
\hline \multirow{2}{*}{ WYSZCZEGÓLNIENIE } & \multicolumn{3}{|c|}{$R S_{p w}$} \\
\hline & 2002 & 2006 & 2010 \\
\hline Francja & 7,6 & b.d. & b.d. \\
\hline Węgry & 19,9 & 20,3 & 24,5 \\
\hline Polska & 20,5 & 17,1 & 9,2 \\
\hline Litwa & 21,2 & 21,4 & 24,8 \\
\hline Łotwa & 23,6 & 25,1 & 18,1 \\
\hline Bułgaria & 23,7 & 27,9 & 16,9 \\
\hline Czechy & 24 & 31,5 & 33,5 \\
\hline Słowacja & 24 & 24,9 & 25,1 \\
\hline Rumunia & 26,1 & b.d. & b.d. \\
\hline Portugalia & 29,4 & b.d. & b.d. \\
\hline Wielka Brytania & 33,2 & 30,1 & 31,1 \\
\hline Estonia & 35,2 & 37,6 & 36,5 \\
\hline Grecja & 35,3 & b.d. & b.d. \\
\hline Finlandia & 39,9 & b.d. & b.d. \\
\hline Stowenia & 40,1 & 30,1 & 28,9 \\
\hline Szwecja & 40,9 & b.d. & b.d. \\
\hline Irlandia & 46 & 26,3 & 19,3 \\
\hline Malta & 46,8 & b.d. & 31,6 \\
\hline Belgia & 47,2 & b.d. & b.d. \\
\hline Holandia & 47,7 & 43,3 & 39,6 \\
\hline Hiszpania & 50 & 42,2 & 31,5 \\
\hline Luksemburg & 51,4 & b.d. & b.d. \\
\hline Dania & 58,3 & b.d. & b.d. \\
\hline Austria & 63 & b.d. & b.d. \\
\hline Niemcy & 65,9 & 47,8 & b.d. \\
\hline Cypr & 67,8 & 64,2 & 57,5 \\
\hline Włochy & 68,6 & b.d. & b.d. \\
\hline
\end{tabular}

b.d. - brak danych

Źródło: opracowanie własne na podstawie: Structure of Earnings Survey 2002, 2006, 2010, Eurostat (20.02.2013).

W porównaniu do analizy wskaźnika $\omega_{\text {III }}$ następujące państwa zmieniły pozycję - Portugalia ( $z$ grupy państw o niskim wskaźniku $X_{29}$, do grupy państw o średnim wskaźniku $X_{30}$,), Belgia i Luksemburg (z grupy państw 
o średnim wskaźniku $X_{32}$, do grupy państw o wysokim wskaźniku $R S_{p w}$ ) oraz Słowacja (z grupy państw o średnim wskaźniku $X_{33}$, do grupy państw o niskim wskaźniku $X_{34}$, ) i Słowenia i Irlandia (z grupy państw o wysokim wskaźniku $S_{p w}$ do grupy państw o średnim wskaźniku $R S_{p w}$ ).

$\mathrm{Na}$ podstawie powyższych danych nie można dokonać natomiast porównań zmian w czasie między poszczególnymi krajami. Można jednakże analizować procentowe zmiany tego wskaźnika w czasie dla wybranych państw - w 10 państwach wskaźnik uległ zmniejszeniu (Polska, Łotwa, Bułgaria, Malta, Wielka Brytania, Hiszpania, Słowenia, Holandia, Irlandia, Cypr), a w 5 zwiększeniu (Węgry, Czechy, Słowacja, Litwa, Estonia).

\section{ZAKOŃCZENIE}

Chcąc przedstawić determinanty wertykalnej segregacji zawodowej oraz ocenić stopnień wertykalnej segregacji płciowej w państwach europejskich, zrealizowano 3 zadania badawcze. Wnioski, jakie wypływają z pierwszego badania, tzn. przedstawienia determinant segregacji wertykalnej wskazanych w teoriach ekonomicznych, wskazują na następujące determinanty segregacji wertykalnej:

1. zaliczanie kobiet do "grup niższego statusu”, "grup stwarzających problemy" lub "grup upośledzonych":

— teoria peryferyjności D. Morse'a wskazuje, że kobiety są pracownikami o statystycznie niższym statusie zawodowym niż mężczyźni, co powoduje, że $z$ jednej strony same obniżają status zawodów sfeminizowanych, a $z$ drugiej nie mają możliwości (albo mają ograniczone możliwości) zajmowania wysokich pozycji w zawodach lub branżach o wyższych statusach;

— teoria dyskryminacji na rynku pracy K. Offe'a i K. Hinrichsa wskazuje, że kobiety pracują w "gorszych” zawodach, w „gorszych” branżach oraz na "gorszych” pozycjach, ponieważ zalicza się je do tzw. grup „stwarzających problemy";

— teoria rynku pracy jako areny R. Loveridge'a i A.L. Moka wskazuje, że kobiety należą do „upośledzonych” grup społecznych, co wynika z ich małych możliwości i chęci zorganizowania się w grupę nacisku;

— racjonalny wybór dokonywany przez kobiety w oparciu o maksymalizację zarobków w ciągu życia oraz oczekiwania co do przyszłych zarobków:

— według hipotezy S. Polacheka segregacja wertykalna wynika z dobrowolnego wyboru dokonywanego przez kobiety opartego o twierdzenie 
o utracie kwalifikacji w związku z przerwami w zatrudnieniu i wyborze zawodu lub pozycji, w których obniżenie płacy jest najmniejsze;

- według hipotezy H. Zellner wiele kobiet nie pracuje dostatecznie długo, by skorzystać ze stopniowego przyrostu płac, dlatego wybierają zawody i pozycje, które charakteryzują się płacami początkowo wyższymi, których przyrost w późniejszym okresie jest bardzo mały.

2. Segmentacja rynku pracy:

- teoria statystycznej segmentacji rynku pracy wskazuje na płeć jako przybliżony wskaźnik posiadania pożądanych (lub niepożądanych) cech wśród pracowników;

— koncepcja rynków zewnętrznych i wewnętrznych wskazuje, że podział rynku pracy na rynki wewnętrzne i rynki zewnętrzne pociąga za sobą segmentację zawodową populacji w oparciu o oczekiwania pracodawców;

- teoria dualnego rynku pracy wskazuje na podział rynku pracy na pierwszorzędny i drugorzędny, który powoduje segregację zawodową w oparciu o podział na „dobre” i „złe” miejsca pracy.

Realizacja drugiego zadania badawczego, czyli analizy wysokości wskaźnika wertykalnej segregacji płciowej w państwach Unii Europejskiej ukazała, że we wszystkich państwach UE udział kobiet w gremiach decyzyjnych i kierowniczych jest mniejszy od udziału kobiet wśród zatrudnionych. Można wyróżnić trzy grupy państw - państwa o niskim wskaźniku wertykalnej segregacji płciowej, do których zaliczono: Francję, Węgry, Polskę, Czechy, Łotwę, Litwę, Portugalię, Bułgarię i Rumunię (w tych państwach udział kobiet w gremiach decyzyjnych i kierowniczych był mniejszy, ale w relatywnie małym stopniu odbiegał od przeciętnego udziału kobiet w zatrudnieniu), państwa o średnim wskaźniku, gdzie udział ten w średnim stopniu odbiegał od przeciętnego udziału - Słowacja, Grecja, Szwecja, Malta, Belgia, Finlandia, Estonia, Wielka Brytania, Luksemburg i państwa o wysokim wskaźniku, gdzie udział ten w znacznym stopniu odbiegał od przeciętnego udziału - Hiszpania, Słowenia, Holandia, Włochy, Dania, Austria, Niemcy, Irlandia i Cypr.

Realizacja trzeciego zadania badawczego, czyli analizy wysokości wskaźnika relacyjnego wertykalnej segregacji płciowej w państwach Unii Europejskiej ukazała, że wskaźnik ten waha się od 7,6 we Francji do aż 68,6 we Włoszech. Można wyróżnić trzy grupy państw - państwa o niskim wskaźniku relacyjnym segregacji płciowej, do których zaliczono: Francję, Węgry, Polskę, Litwę, Łotwę, Bułgarię, Czechy, Słowację i Rumunię, państwa o średnim wskaźniku - Portugalia, Wielka Brytania, Estonia, Grecja, Finlandia, Słowenia, Szwecja, Irlandia, Malta i państwa o wysokim wskaźniku - Belgia, Holandia, Hiszpania, Luksemburg, Dania, Austria, Niemcy, Cypr i Włochy. 


\section{BIBLIOGRAFIA}

Bergman B.R., The Effect on White Incomes of Discrimination in Employment, "Journal of Political Economy" vol. 79 No. 2/ 1971, s. 294-313, http://dx.doi. org/10.1086/259744.

Doeringer P., Piore M., Internal Labor Markets and Manpower Analysis, D.C. Heath, Lexington Mass. 1971.

Edgeworth F.Y., Equal pay to men and women for equal work, „Economic Journal” nr 32/1922, s. 431-457, http://dx.doi.org/10.2307/2223426.

England P., Wage Appreciation and Depreciation: A Test of Neoclassical Economic Explanations of Occupational Sex Segregation, „Social Forces” nr 3 (62)/1984, s. 50-75, http://dx.doi.org/10.2307/2578708.

Gawrycka M., Wasilczuk J., Zwiech P., Szklany sufit i ruchome schody - kobiety na rynku pracy, CeDeWu sp. z o.o., Warszawa 2007.

Kallenberg A.L., Sorensen K., The Socjology of Labor Markets, „Annual Review of Socjology" nr 5/1979, s. 351-379.

Loveridge R., Mok A.L., Theories of Labour Market Segmentation. A Critique, Martinus Nijhof, Hague - Boston - London 1979.

Morse D., The Peripheral Worker, Columbia University Press, London 1969.

Piore M., The Dual Labor Market. Theory and Applications, [w:] R. Barringer, S.H. Beer (red.), The State and the Poor, Winthrop, Cambridge Mass 1970.

Piore M.J., Notes for Theory of Labor Market Stratification, [w]: R.C. Edwards, M. Reich, D.M. Gordon (red.), Labor Market Segmentation, D.C. Heath, Lexington Mass. 1975.

Polachek S., Occupational Segregation among Women: Theory, Evidence and a Prognosis, [w]: C. Lloyd (red.), Women in the Labor Market, Columbia University Press, Columbia 1979.

Reszke I., Nierówności ptci w teoriach. Teoretyczne wyjaśnienia nierówności ptci w sferze pracy zawodowej, IFIS PAN, Warszawa 1991.

Sloane P.J., Sex Differentials: Structure, Stability and Change, [w]: N. Gregory, W. Thomson (red.) A Portrait of Pay 1970-1982: An Analysis of the New Earnings Survey, Clarendon, Oxford 1990.

Zellner H., The Determinants of Occupational Segregation, [w]: C. Lloyd (red.), Sex, Discrimination and the Division of Labor, Columbia University Press, Columbia 1975.

Zwiech P., Rodzaje dyskryminacji kobiet na rynku pracy, „Polityka Społeczna” nr 4/2011. 
